Article

\title{
Evaluating the Struvite Recovered from Anaerobic Digestate in a Farm Bio-Refinery as a Slow-Release Fertiliser
}

\author{
Magdalena Szymańska ${ }^{1, *(\mathbb{D})}$, Tomasz Sosulski ${ }^{1}{ }^{\mathbb{D}}$, Adriana Bożętka $^{1}$, Urszula Dawidowicz $^{1}$, \\ Adam Wąs ${ }^{2}{ }^{\circledR}$, Ewa Szara ${ }^{1}$, Agata Malak-Rawlikowska ${ }^{2}$, Piotr Sulewski ${ }^{2}{ }^{\mathbb{D}}$, \\ Gijs W. P. van Pruissen ${ }^{3}$ and René L. Cornelissen ${ }^{3}$ \\ 1 Department of Agricultural Chemistry, Institute of Agriculture, Warsaw University of Life Sciences-SGGW, \\ Nowoursynowska 159, 02-766 Warsaw, Poland; tomasz_sosulski@sggw.edu.pl (T.S.); \\ abozetka@onet.pl (A.B.); ula.dawidowicz1@gmail.com (U.D.); ewa_szara@sggw.edu.pl (E.S.) \\ 2 Institute of Economics and Finances, Warsaw University of Life Sciences-SGGW, Nowoursynowska 166, \\ 02-787 Warsaw, Poland; adam_was@sggw.edu.pl (A.W.); agata_malak_rawlikowska@sggw.edu.pl (A.M.-R.); \\ piotr_sulewski@sggw.edu.pl (P.S.) \\ 3 Cornelissen Consulting Services BV, Binnensingel 3, 7411 PL Deventer, The Netherlands; \\ vanpruissen@ccsenergieadvies.nl (G.W.P.v.P.); Cornelissen@ccsenergieadvies.nl (R.L.C.) \\ * Correspondence: magdalena_szymanska@sggw.edu.pl; Tel.: +48-22-593-26-27
}

Received: 27 August 2020; Accepted: 12 October 2020; Published: 14 October 2020

check for updates

\begin{abstract}
Biogas production in agricultural biogas plants generates digestate-liquid waste containing organic matter and mineral nutrients. Utilisation of the digestate on farm fields adjacent to the biogas plants is limited. Therefore, bio-refineries implement advanced forms of digestate processing, including precipitation of struvite $\left(\mathrm{MgNH}_{4} \mathrm{PO}_{4} \cdot 6 \mathrm{H}_{2} \mathrm{O}\right)$. Struvite can be transported over long distances and dosed precisely to meet the nutritional needs of the plants. Divergent opinions on the fertilising value of struvite and its function over time call for further research on its effects on crop yields in the first and subsequent years after application. This study investigates the effects of struvite (STR), struvite with ammonium sulphate $(\mathrm{STR}+\mathrm{N})$, and commercial ammonium phosphate (AP) on the yields, nutrient concentration in the crops, nutrient uptake by the crops, and soil N, P, and Mg content in the second growing period after the application of fertilisers to silty loam (SL) and loamy sand (LS) soils under grass cultivation. Struvite was recovered from the liquid fraction of digestate obtained from a bio-refinery on the De Marke farm (Netherlands). The soils investigated in the pot experiment originated from Obory (SL) and Skierniewice (LS) (Central Poland). The results obtained over the first growing period following fertilisation were published earlier. In our prior work, we showed that the majority of the struvite phosphorus remains in the soil. We hypothesised that, in the second year, the yield potential of the struvite might be higher than that of commercial P fertiliser. Currently, we have demonstrated that, in the second growing period following the application, struvite causes an increase in grass yield, nutrient uptake by the crops, and P and Mg content in the soil. On SL and LS soils, the yields of the four grass harvests from the STR and STR + N treatments were higher than those from AP by approximately $8 \%$ and $16.5 \%$, respectively. Our results confirm that struvite is more effective as a fertiliser compared to commercial ammonium phosphate. Struvite can be, therefore, recommended for fertilising grasslands at higher doses once every two years.
\end{abstract}

Keywords: struvite; fertiliser value; biogas plant; farm bio-refinery; $\mathrm{P}$ and $\mathrm{N}$ recovery 


\section{Introduction}

The recent growth in demand for biomass for consumption, fodder, and energy purposes triggered an increase in demand for fertiliser components. As a consequence, an increase in the application of mineral fertilisers can soon become the cause of exhaustion of the global resources of raw materials used for fertiliser production [1]. Approximately 180-190 million tonnes of phosphate rocks are mined annually [2]. Approximately $95 \%$ of the global depletion is allocated for agricultural purposes, primarily for the production of mineral fertilisers, and to a lower degree for the production of pesticides and feedstuff additives. The exhaustion of resources of high-quality phosphorites leads to the exploitation of deposits with a low phosphorus content and containing contaminants, e.g., heavy metals [3]. As a consequence, the future cost of extraction and treatment of the mined minerals, and therefore the production of phosphorus fertilisers, is expected to increase. An increase in fertiliser prices in global markets will cause an increase in food prices [4].

Currently, the phosphorus management in agricultural production has a character of an open cycle. This causes phosphorus not utilised in the production processes to be accumulated in the soils or released into the waters, intensifying their eutrophication. In this context, fertiliser use of unprocessed, and particularly the processed organic and inorganic waste and substances recovered from it is gaining new importance [5]. Research is currently being conducted, and innovative technologies have been implemented at a large scale for recovering phosphorus from organic waste and wastewater available at the local scale [6-8]. Popularisation of such solutions will allow for rational phosphorus management, involving closing its cycle in the environment, and recovering it for subsequent production cycles. One of the types of waste that is subject to phosphorus recovery is digestate from biogas plants (AD). $\mathrm{AD}$ plants have spread around the globe in the last decade, especially in China (26.5 million plants), Europe (17,240 plants), and the USA (1497 plants) [9]. In the Czech Republic, for instance, the number of AD plants increased from 320 in 2012 [10] to 600 in mid-2018 [11]. An increasing number of AD plants is associated with an increase in the amount of the by-product-digestate. Digestate is a liquid product containing a significant quantity of soluble forms of nutrients (e.g., ammonium, phosphate, and potassium), and the remaining solids [12]. The transport and disposal of the continuously produced digestate is problematic on a local or even regional scale [13]. Solid-liquid separation of the digestate is therefore often used in AD plants. The solid fraction of digestate is usually applied as an organic fertiliser. The disposal of the liquid fraction of digestate is more problematic due to its low solids content and relatively high content of soluble forms of nutrients [14]. Research on the liquid fraction of digestates has rapidly intensified in recent years, covering struvite recovery [15], ammonia stripping, vacuum evaporation [16], and microalgae or duckweed cultivation [17]. The research primarily focuses on determining the effectiveness of particular recovery processes [18-20]. It is necessary, however, to valorise and assess their suitability, including the fertiliser value of the recovered products, e.g., struvite or ammonium sulphate. Lack of research on product quality increases the risks involved in their industrial-scale application [21].

Struvite is a crystal weakly soluble in water. Only $3 \%$ of the total $P$ is soluble in water [22]. Struvite applied to the soil slowly releases forms of phosphorus available for plants. This differentiates it from mineral phosphorus fertilisers that rapidly dissolve in a soil solution [23]. Despite the application of phosphorus doses corresponding with the nutrition requirements of plants, insufficient solubility of struvite can limit the growth and development, and consequently yields, of plants [24]. The rate of phosphorus released from struvite may be insufficient for fast $\mathrm{P}$ uptake, particularly during the early stages of plant growth [25]. Cabeza et al. [25] suggested, however, that the solubility of recycled $P$ products in water or $2 \%$ citric acid was not a good indicator of their effectiveness as $P$ fertilisers. Cabeza et al. [26] and Bonvin et al. [24] reported that phosphorus solubility and uptake by plants from struvite was approximate to that from mineral phosphorus fertilisers, e.g., superphosphate and potassium phosphate $\left(\mathrm{KH}_{2} \mathrm{PO}_{4}\right)$, respectively. In the literature, struvite has been described as a highly effective, slow-releasing $\mathrm{P}$ fertiliser [27] free of pathogens and heavy metals [21,28,29]. It is a good alternative to artificial fertilisers [30]. Plaza et al. [31], Liu et al. [32], and Antonini et al. [33] reported 
that the struvite recovered from organic waste was as effective for elevating crop-yielding as artificial phosphorus fertilisers. Gonzales-Ponce et al. [34] and Szymańska et al. [35] reported that struvite was even more effective than commercial phosphorus fertilisers. Higher yields obtained as a result of struvite application than those in the case of commercial phosphorus fertilisers could have resulted from the presence of magnesium and the synergistic effect of the $\mathrm{P}$ and $\mathrm{Mg}$ ratio in struvite on the growth and yielding of plants [21]. According to Ackerman et al. [36], however, the fertiliser value of struvite was lower than that of commercial phosphorus fertilisers. Degryse et al. [22] explained this discrepancy in the fertiliser application method used by Ackerman [36] (banded versus mixed through the soil in the other studies). The majority of studies assessing the fertiliser value of struvite consisted of one-year experiments. A meta-analysis of the agricultural potential of struvite as a phosphorus fertiliser [37] showed that the duration of the experiments varied from 11 days (grass, garden cress, and purslane) to 140 days (grass). Moreover, according to the cited authors, the global literature provides limited studies conducted in European soil and climatic condition [37]. This makes a proper assessment of the fertiliser value of struvite even more difficult because is it closely related to the soil type and its properties [21].

Because struvite is a product that slowly dissolves in soil, we hypothesised that, in the second year after struvite application, its yield potential might be higher than that of a commercial $P$ fertiliser (ammonium phosphate). Because the type of soil is a key factor for the availability of phosphorus from struvite, we assessed the fertiliser value of struvite recovered from the liquid fraction of anaerobically digested slurry from a dairy farm bio-refinery using two types of soils, namely, silty loam and loamy sand soils typical of Central and Eastern Europe.

\section{Materials and Methods}

\subsection{Farm Bio-Refinery}

The farm-scale bio-refinery was located at the experimental dairy farm "De Marke" in Hengelo (Gld), the Netherlands (the operation diagram and description of the bio-refinery are presented in other authors' work [38]). Anaerobic digestion of cattle slurry was conducted in the bio-refinery. The electricity and heat were produced from the obtained biogas. The resulting digestate was separated into the solid and liquid fraction employing a mechanical separator. The solid fraction was applied to the soil of the farm. Nitrogen and phosphorus were recovered from the liquid fraction of digestate. At the first stage, phosphorus and nitrogen were recovered through precipitation of struvite $\left(\mathrm{MgNH}_{4} \mathrm{PO}_{4} \cdot 6 \mathrm{H}_{2} \mathrm{O}\right)$. The struvite was the first commercial product obtained in the bio-refinery. The effluent remaining after struvite precipitation was alkalised and heated. The released ammonia was bound with sulphuric acid to ammonium sulphate. Ammonium sulphate was the second commercial product obtained in the bio-refinery. The effluent after nitrogen and phosphorus recovery was fed to a container used for cultivation of duckweed for cattle feedstuff.

\subsection{Pot Experiment}

A detailed description of the pot experiment was presented in an earlier work by the authors [35]. The vegetation experiment was established in 2017 in a greenhouse belonging to the Warsaw University of Life Sciences. The pot experiment was conducted from May 2017 to September 2018 in three repetitions, in a fully random system. The experiment involved the use of two soils, namely silty loam (SL) and loamy sand (LS). The soils used in the experiment were characterised by the following physico-chemical properties: soil SL- $\mathrm{pH}$ 6.3; total nitrogen $\left(\mathrm{g} \mathrm{kg}^{-1}\right)$ 2.6; active forms $\left(\mathrm{mg} \mathrm{kg}^{-1}\right.$ ) of $\mathrm{P}_{\mathrm{CaCl} 2}$ 14.6; $\mathrm{Mg}_{\mathrm{CaCl} 2} 187.9$; available forms $\left(\mathrm{mg} \mathrm{kg}^{-1}\right.$ ) of $\mathrm{P}_{\mathrm{M} 3}$ 87.2; $\mathrm{Mg}_{\mathrm{M} 3} 306.2$. Soil LS- $\mathrm{pH}$ 6.3; total $\mathrm{N}\left(\mathrm{g} \mathrm{kg}^{-1}\right)$ 0.8; active forms $\left(\mathrm{mg} \mathrm{kg}^{-1}\right)$ of: $\mathrm{P}_{\mathrm{CaCl}} 19.1$; $\mathrm{Mg}_{\mathrm{CaCl}} 20.0$; available forms $\left(\mathrm{mg} \mathrm{kg}^{-1}\right)$ of $\mathrm{P}_{\mathrm{M} 3} 95.7 ; \mathrm{Mg}_{\mathrm{M} 3} 65.0$ [35]. The tested struvite contained $23.1 \mathrm{~g} \mathrm{~N} \mathrm{~kg}^{-1}, 39.4 \mathrm{~g} \mathrm{P} \mathrm{kg}^{-1}$, and $32.3 \mathrm{~g} \mathrm{Mg} \mathrm{kg}^{-1}$ [35]. The fertiliser value of the following fertilisers was compared with the control treatment (KTR-without N, P, or Mg fertilisation): struvite-STR; struvite with ammonium sulphate 
(AS)—STR + N; and commercial ammonium phosphate fertilizer-AP. In May 2017, the examined substances were applied to each pot at the following rates shown in Table 1.

Table 1. Doses of compared nutrients in the pot experiment.

\begin{tabular}{|c|c|c|c|}
\hline Treatment & $\mathbf{P}(\mathrm{g})$ & N (g) & $\operatorname{Mg}(g)$ \\
\hline Struvite (STR) & 2.0 & 1.17 & 1.6 \\
\hline Struvite with ammonium sulphate (STR + N) & 2.0 & $\begin{array}{c}1.8 \\
(1.17 \text { as STR and } 0.63 \text { as AS) }\end{array}$ & 1.6 \\
\hline Commercial ammonium phosphate fertiliser (AP) & 2.0 & 1.8 & 0 \\
\hline Control treatment (KTR) & 0 & 0 & 0 \\
\hline
\end{tabular}

Source: Szymańska et al., 2019 [35].

No fertilisation was applied in 2018. The grass Lolium multiflorum was cultivated. In the first year (2017), three grass harvests were collected (the yield potential of the applied struvite was described in an earlier work of the authors [35]). In the second year of the experiment (2018), four grass harvests were collected. Soil and plant samples were taken from each pot once, after harvesting.

\subsection{Analytical Procedures of the Experiment}

The plant samples (above-ground biomass) were dried in an oven set at $60{ }^{\circ} \mathrm{C}$ and mineralized using a DK 20 digestion unit model (VELP Scientifica, Usmate, Italy). The content of magnesium $(\mathrm{Mg})$ in the crops was measured using an atomic absorption spectrometer (AAS) (SOLAAR, Thermo Elemental, Cambridge, UK), while the content of $\mathrm{P}$ was tested by the vanadomolybdophosphoric method using the spectrophotometer Genesys 10 UV-VIS (Thermo Electron Corporation, Madison, WI, USA). The total $\mathrm{N}$ content $\left(\mathrm{N}_{\text {tot }}\right)$ in the crops and soils was measured employing the Kjeldahl method using the Vapodest analyser model VAP 30 (Gerhardt, Bonn, Germany). Total nutrient (N, P, and $\mathrm{Mg}$ ) uptake was calculated from the above-ground biomass dry matter and above-ground biomass nutrient concentration. Soil $\mathrm{pH}$ (in $1 \mathrm{~mol} \mathrm{dm}^{-3} \mathrm{KCl}$ ) was determined using a $\mathrm{pH}$ meter (Schott, Mainz, Germany); the content of the available phosphorus and magnesium forms $\left(\mathrm{P}_{\mathrm{M} 3}, \mathrm{Mg}_{\mathrm{M} 3}\right)$ was determined using the Mehlich-3 method. The content of the active forms of phosphorus $\left(\mathrm{P}_{\mathrm{CaCl}}\right)$ and magnesium ( $\mathrm{Mg}_{\mathrm{CaCl} 2}$ ) was measured (in $0.01 \mathrm{~mol} \mathrm{dm}^{-3} \mathrm{CaCl}_{2}$ ) using the molybdenum-blue ascorbic and AAS methods, respectively.

\subsection{Phosphorus- and Nitrogen-Use Efficiency}

The related fertiliser efficiency $\left(\mathrm{RFE}_{\mathrm{P}}\right.$ and $\mathrm{RFE}_{\mathrm{N}}$ ) was used as a parameter to rank the $\mathrm{P}$ or $\mathrm{N}$ sources in comparison to ammonium phosphate (AP) [35]. The indicators were calculated as follows:

$$
\operatorname{RFE}_{\mathrm{P}(\mathrm{N})}(\%)=\frac{\mathrm{P}(\mathrm{N}) \text { uptake on STR or STR }+\mathrm{N}-\mathrm{P}(\mathrm{N}) \text { uptake on KTR }}{\mathrm{P}(\mathrm{N}) \text { uptake on AP }-\mathrm{P}(\mathrm{N}) \text { uptake on KTR }} * 100
$$

$\mathrm{RFE}_{\mathrm{P}}$-related fertiliser efficiency-phosphorus;

$\mathrm{RFE}_{\mathrm{N}}$-related fertiliser efficiency-nitrogen;

STR-treatment with struvite;

$\mathrm{STR}+\mathrm{N}$-treatment with struvite with ammonium sulphate;

AP—treatment with ammonium phosphate KTR—control treatment—no fertilisers applied.

An apparent fertiliser nutrient ( $\mathrm{P}$ and $\mathrm{N}$ ) recovery (APR and ANR, respectively) was calculated as follows according to the formulae:

$$
\mathrm{AP}(\mathrm{N}) \mathrm{R}=\frac{\mathrm{P}(\mathrm{N}) \text { uptake on STR or STR }+\mathrm{N} \text { or AP }-\mathrm{P}(\mathrm{N}) \text { uptake on } \mathrm{KTR}}{\mathrm{P}(\mathrm{N}) \text { dose per pot }} * 100
$$




\subsection{Statistical Analysis}

Statistical analyses were carried out using the Statistica PL 13.3 software (TIBCO Software Inc., Tulsa, OK, USA). One-way analysis of variance (ANOVA) was carried out to determine any statistically significant differences between treatments (at $p<0.05$ ). Homogeneous groups for the examined treatments were determined by Tukey's (HSD) multiple-comparison test.

\section{Results and Discussion}

\subsection{Crop Yields}

Irrespective of the fertilisation applied in the experiment, higher grass yields were obtained in SL soil with a higher content of clay (mean $62 \mathrm{~g}$ dry matter (D.M.) pot $^{-1}$ ) than in LS soil (mean 49 g D.M. pot $^{-1}$ ) (Figure 1). Yields of grass cultivated in SL soil significantly $(p<0.05)$ differs regarding the fertilisation applied. The highest accumulated yield of the four grass harvests in SL soil was obtained in the treatment fertilised with STR + N (70.6 g D.M. pot $\left.{ }^{-1}\right)$, lower in the STR (63.9 g D.M. pot ${ }^{-1}$ ) and AP treatment (62.3 g D.M. pot ${ }^{-1}$ ), and the lowest in the KTR treatment (50.6 g D.M. pot $^{-1}$ ). In LS soil, the accumulated yields of the four grass harvests obtained from both treatments fertilised with struvite (STR and STR + N) were similar (mean 52.7 g D.M. pot ${ }^{-1}$ ), and more than $16 \%$ higher than from the AP and KTR treatments (mean 45.3 g D.M. pot ${ }^{-1}$ ). Grass yields obtained in subsequent harvests were variable. Irrespective of the fertilisation and type of soil, grass yields collected in the second harvest were higher than in the remaining harvests. In LS soil, the significance of the differences in grass yields was only evidenced for the second and third harvest. In SL soil, grass yields obtained from subsequent harvests in treatments fertilised with struvite were usually higher than from the KTR treatment and similar to those obtained from the AP treatment. In LS soil, the yields of the third harvest of grass fertilised with STR and STR $+\mathrm{N}$ and the second harvest fertilised with STR $+\mathrm{N}$ were significantly higher $(p<0.05)$ than those obtained from the AP treatment. Irrespective of the harvest, grass yields collected from the LS soil fertilised with ammonium phosphate were similar to those from the KTR treatment (Figure 1).

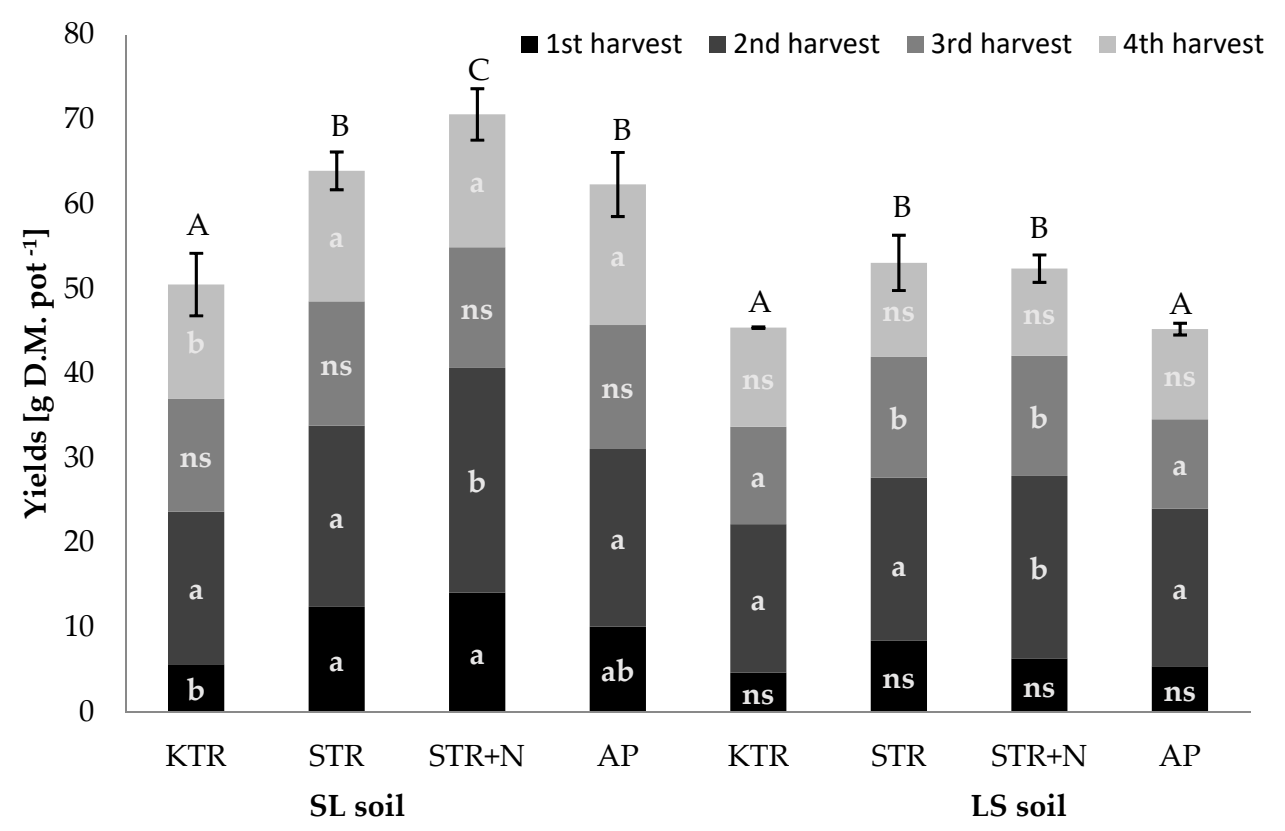

Figure 1. Yields (D.M.-Dry Matter) of grass (sum of four harvests) on the two types of soil: silty loam (SL) and loamy sand (LS). Values followed by the same letters (a-b: for every harvest: 1 st-4th, and A-C for sum of four harvests-separately for soils: SL and LS) are not statistically different $(p<0.05)$; ns: not significant. The standard deviation within each treatment $(n=3)$ is indicated by the line extending from the column. 
Previous international studies are in agreement with our findings. Plaza et al. [31] conducted a pot experiment on the P-poor loamy sand soil and showed that struvite and single superphosphate increased the yield of the dry matter of ryegrass and provided crops with phosphorus in a similar way. Reza et al. [39] reported that fresh (F.M.) and dry matter (D.M.) yield of Sudan grass was significantly higher on the struvite treatment than on the control treatment, but no significant differences among the struvite- (230.4 g F.M. pot $^{-1}$ and 55.5 g D.M. pot ${ }^{-1}$ ) and superphosphate-treated plants (222.3 g F.M. pot ${ }^{-1}$ and 53.1 g D.M. pot ${ }^{-1}$ ) were observed. Johnston and Richards [40] also found an insignificant difference in the effectiveness of struvite and artificial monocalcium phosphate for ryegrass growth and total dry matter. Bonvin et al. [24] obtained higher yields of ryegrass (Lolium multiflorum var. Gemini) cultivated on soil with a sandy loam texture on treatments fertilised with struvite than on the control (without fertilisation with nitrogen or phosphorus). Yetilmezsoy et al. [41] tested struvite in garden rocket (Eruca sativa), dill (Anethum graveolens), fennel (Foeniculum vulgare), and parsley (Petroselinum crispum) cultivation in a greenhouse experiment. The obtained results showed that the rates of increase in the dry matter of plants cultivated on soil fertilised with the recovered struvite reached $488 \%$ for garden rocket, $191 \%$ for dill, $379 \%$ for fennel, and $208 \%$ for parsley, respectively, in relation to the control treatment. Greater yielding of maize and tomato, mung bean, and lettuce fertilised with struvite than with commercial fertilisers was obtained in several studies [34,42-45]. Kern et al. [46]—who tested wheat and maize, Ryu et al. [47]—Chinese cabbage and lettuce, and Diwani et al. [48] — broad bean, also obtained an increase in plant yielding after struvite application. Gell et al. [45] and Liu et al. [32] obtained a similar effectiveness of struvite and commercial mineral fertiliser in maize, rapeseed, and winter barley cultivation.

Our study confirms that the yield potential of struvite is manifested one year after its application to the soil. Struvite could be applied at high doses once in several years for the fertilisation of meadows and trees stands [21]. Recommending such fertilisation requires a preceding assessment of the possibilities of dispersal of phosphorus from struvite to the environment. Available data indicated that phosphorus release from several recovered struvites was much slower than from the artificial fertiliser (superphosphate) [39]. Rahman et al. [49] also observed a lower release of $P$ from struvite $(0.03 \%)$ compared to commercial superphosphate fertiliser $(0.23 \%)$ after application of $30-40 \mathrm{~kg} \mathrm{ha}^{-1}$ to the soil. Latifian et al. [50] observed that $88 \%$ of the phosphorus was released from artificial NPK fertiliser to the soil in a period over 20 days after its application. The recovered struvite released only $12 \%$ of phosphorus after 105 days of the experiment. These results confirm that struvite is more eco-friendly as a fertiliser source compared to artificial fertilisers due to the slow release of nutrients into the soil. Thus, using struvite is decreasing P leaching [39], and is increasing the yield even a year after its application to the soil.

\subsection{Nutrient Content in Plants}

The applied fertilisation substantially contributed to the content of the analysed elements in the grass biomass (Table 2). Ryu et al. [47] reported that the struvite sources provided the content of crop macronutrients in Chinese cabbage as much as other commercial fertilisers, particularly struvite increased the amount of phosphorus in plants. In conducted study, mean total nitrogen content in particular grass harvests on treatments with different fertilisation of soil SL varied from 21.2 to $26.4 \mathrm{~g} \mathrm{~N} \mathrm{~kg}^{-1}$ D.M., and in LS soil from 21.2 to $24.3 \mathrm{~g} \mathrm{~N} \mathrm{~kg}^{-1}$ D.M. Nitrogen content in plants collected in subsequent harvests on treatments fertilised with struvite (STR, and STR $+\mathrm{N}$ ) was usually similar to that on AP treatment. Only in the first harvest, grass fertilised with STR contained significantly $(p<0.05)$ more nitrogen than on AP treatments. 
Table 2. Nutrients-nitrogen $(\mathrm{N})$, phosphorus $(\mathrm{P})$, and magnesium $(\mathrm{Mg})$ content in plants in $\mathrm{g} \mathrm{kg}^{-1}$ D.M.

\begin{tabular}{|c|c|c|c|c|c|c|c|c|c|c|c|c|}
\hline \multirow{3}{*}{ Fertilisation } & \multicolumn{4}{|c|}{$\mathbf{N}$} & \multicolumn{4}{|c|}{$\mathbf{P}$} & \multicolumn{4}{|c|}{$\mathrm{Mg}$} \\
\hline & $\begin{array}{c}\text { 1st } \\
\text { Harvest }\end{array}$ & $\begin{array}{c}\text { 2nd } \\
\text { Harvest }\end{array}$ & $\begin{array}{c}\text { 3rd } \\
\text { Harvest }\end{array}$ & $\begin{array}{c}\text { 4th } \\
\text { Harvest }\end{array}$ & $\begin{array}{c}\text { 1st } \\
\text { Harvest }\end{array}$ & $\begin{array}{c}\text { 2nd } \\
\text { Harvest }\end{array}$ & $\begin{array}{c}\text { 3rd } \\
\text { Harvest }\end{array}$ & $\begin{array}{c}\text { 4th } \\
\text { Harvest }\end{array}$ & $\begin{array}{c}\text { 1st } \\
\text { Harvest }\end{array}$ & $\begin{array}{c}\text { 2nd } \\
\text { Harvest }\end{array}$ & $\begin{array}{c}\text { 3rd } \\
\text { Harvest }\end{array}$ & $\begin{array}{c}\text { 4th } \\
\text { Harvest }\end{array}$ \\
\hline & \multicolumn{12}{|c|}{ SL soil } \\
\hline KTR & $23.5 c$ & $34.1 \mathrm{~ns}$ & $26.5 \mathrm{~b}$ & $21.7 \mathrm{~b}$ & $4.7 \mathrm{c}$ & $3.0 \mathrm{~ns}$ & $2.8 \mathrm{~ns}$ & $2.5 \mathrm{a}$ & $4.1 \mathrm{~b}$ & $3.4 \mathrm{a}$ & $3.6 \mathrm{~ns}$ & $4.6 \mathrm{~ns}$ \\
\hline STR & $17.4 \mathrm{~b}$ & $27.8 \mathrm{~ns}$ & $22.0 \mathrm{a}$ & $19.6 \mathrm{ab}$ & $3.3 \mathrm{ab}$ & $2.9 \mathrm{~ns}$ & $3.5 \mathrm{~ns}$ & $3.6 \mathrm{~b}$ & $3.7 \mathrm{ab}$ & $4.3 \mathrm{ab}$ & $3.6 \mathrm{~ns}$ & $4.9 \mathrm{~ns}$ \\
\hline $\mathrm{STR}+\mathrm{N}$ & $14.0 \mathrm{ab}$ & $31.3 \mathrm{~ns}$ & $22.0 \mathrm{a}$ & $17.5 \mathrm{a}$ & $2.9 \mathrm{a}$ & $3.3 \mathrm{~ns}$ & $2.9 \mathrm{~ns}$ & $3.7 \mathrm{~b}$ & $3.6 \mathrm{a}$ & $5.1 \mathrm{~b}$ & $4.3 \mathrm{~ns}$ & $5.0 \mathrm{~ns}$ \\
\hline \multirow[t]{2}{*}{$\mathrm{AP}$} & $13.6 \mathrm{a}$ & $31.7 \mathrm{~ns}$ & $22.9 \mathrm{ab}$ & $21.5 \mathrm{~b}$ & $4.2 \mathrm{bc}$ & $3.3 \mathrm{~ns}$ & $2.8 \mathrm{~ns}$ & $2.3 \mathrm{a}$ & $3.3 \mathrm{a}$ & $4.4 \mathrm{ab}$ & $3.8 \mathrm{~ns}$ & $5.0 \mathrm{~ns}$ \\
\hline & \multicolumn{12}{|c|}{ LS soil } \\
\hline KTR & $15.7 \mathrm{bc}$ & $29.8 \mathrm{~ns}$ & $24.4 \mathrm{a}$ & $14.9 \mathrm{a}$ & $5.3 \mathrm{~ns}$ & $2.5 \mathrm{a}$ & $3.6 \mathrm{~b}$ & $3.2 \mathrm{a}$ & $3.6 \mathrm{ab}$ & $3.2 \mathrm{a}$ & $2.9 \mathrm{a}$ & $4.2 \mathrm{a}$ \\
\hline STR & $16.1 \mathrm{c}$ & $33.7 \mathrm{~ns}$ & $27.7 \mathrm{~b}$ & $19.8 \mathrm{~b}$ & $6.4 \mathrm{~ns}$ & $4.3 \mathrm{~b}$ & $1.8 \mathrm{a}$ & $4.5 \mathrm{ab}$ & $5.1 \mathrm{~b}$ & $5.8 \mathrm{~b}$ & $4.9 \mathrm{~b}$ & $5.4 \mathrm{~b}$ \\
\hline $\mathrm{STR}+\mathrm{N}$ & $11.8 \mathrm{a}$ & $34.7 \mathrm{~ns}$ & $22.7 \mathrm{ab}$ & $17.1 \mathrm{ab}$ & $6.2 \mathrm{~ns}$ & $3.7 \mathrm{ab}$ & $3.6 \mathrm{~b}$ & $7.2 \mathrm{c}$ & $8.4 \mathrm{c}$ & $5.3 \mathrm{~b}$ & $6.4 \mathrm{c}$ & $5.9 \mathrm{~b}$ \\
\hline $\mathrm{AP}$ & $13.5 \mathrm{ab}$ & $31.0 \mathrm{~ns}$ & $25.3 \mathrm{ab}$ & $17.4 \mathrm{ab}$ & $5.1 \mathrm{~ns}$ & $4.6 \mathrm{~b}$ & $4.6 \mathrm{c}$ & $5.3 \mathrm{~b}$ & $3.1 \mathrm{a}$ & $4.1 \mathrm{ab}$ & $3.4 \mathrm{a}$ & $4.3 \mathrm{a}$ \\
\hline
\end{tabular}

Values followed by the same letters $(\mathrm{a}-\mathrm{c})$ in the column (separately for soils: SL and LS) are not statistically different $(p<0.05)$; ns: not significant. 
Mean phosphorus content in plants cultivated in LS soil was 41\% higher than in SL soil. Mean phosphorus content in particular grass harvests on SL treatments with different fertilisation varied from 3.1 to $3.3 \mathrm{~g} \mathrm{P} \mathrm{kg}^{-1}$ D.M., and in LS soil from 3.6 to $5.2 \mathrm{~g} \mathrm{P} \mathrm{kg}^{-1}$ D.M. In SL soil, the biomass of the fourth harvests of grass fertilised with STR and STR $+\mathrm{N}$ contained significantly $(p<0.05)$ more phosphorus than in the AP treatment. Regarding the nutrient content in the biomass of the 1st-3rd grass harvests, the impact of struvite on the P content in the biomass for the STR and STR + N treatments was the same as for the AP treatment. Similar results were obtained in LS soil, where only the fourth harvest of grass fertilised with STR $+\mathrm{N}$ contained more $\mathrm{P}$ than that of the AP treatment.

The mean magnesium content in plants cultivated in LS soil was approximately $13 \%$ higher than in SL soil. The mean magnesium content in specific grass harvests on treatments with different fertilisation of soil SL varied from 3.9 to $4.5 \mathrm{~g} \mathrm{Mg} \mathrm{kg}^{-1}$ D.M., while in LS soil from 3.5 to $6.5 \mathrm{~g} \mathrm{Mg} \mathrm{kg}^{-1}$ D.M. In SL soil, no significant $(p<0.05)$ differences were found in Mg content in the grass (harvests 1st-4th) between the treatments fertilised with STR, STR $+\mathrm{N}$, and AP (Table 2). In LS soil, the biomass of all four grass harvests contained more $\mathrm{Mg}$ in the treatments fertilised with STR and STR $+\mathrm{N}$ than in the AP treatment. The obtained results can be explained by the fact that the SL soil contained more forms of magnesium available for plants than the LS soil. Due to this, in SL soil, grass could uptake magnesium from the soil resources, and in LS soil, struvite could be the primary source of magnesium.

\subsection{Nutrient Uptake by Plants}

Irrespective of the experimental fertilisation, grass cultivated in SL soil took up more nitrogen than in LS soil (Figure 2). In SL soil, no significant differences $(p>0.05)$ were found in nitrogen uptake by grass fertilised with struvite (STR and STR $+\mathrm{N}$ ) and ammonium phosphate (AP). In LS soil, nitrogen uptake by grass fertilised with STR and STR + N was significantly higher-by more than $26 \%$ (1397.4 mg N pot ${ }^{-1}$ and $1318.2 \mathrm{mg} \mathrm{N}$ pot $^{-1}$, respectively) than the AP treatment (1099.6 $\mathrm{mg} \mathrm{N} \mathrm{pot}^{-1}$ ) and KRT treatment (1048.3 $\left.\mathrm{mg} \mathrm{N} \mathrm{pot}^{-1}\right)$.

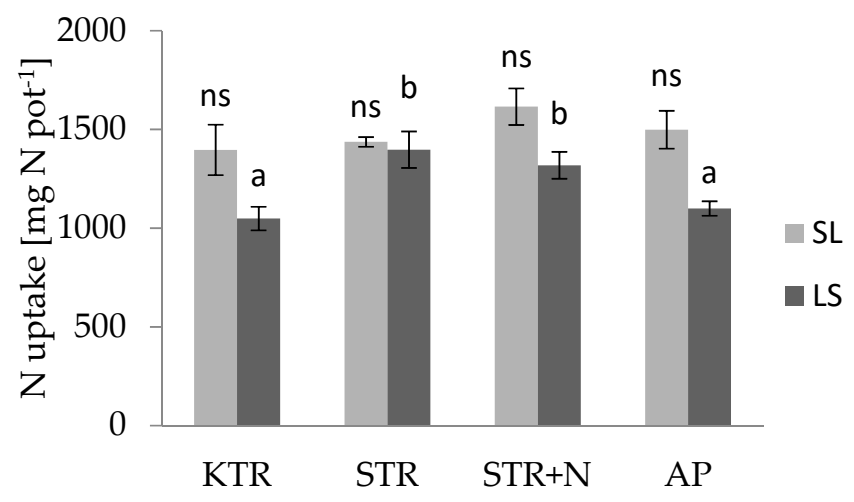

Figure 2. Uptake of $\mathrm{N}$ (sum for four harvests) by grass. The standard deviation within each treatment $(n=3)$ is indicated by the line extending from the column. Different letters $(a, b)$ indicate significant differences $(p<0.05)$; ns: not significant.

In both soils (SL and LS), P uptake by grass fertilised with STR and STR + N was significantly $(p<0.05)$ higher than in the KTR treatment (on average for STR and STR $+\mathrm{N}$ by approx. $43 \%$ in SL soil and $95 \%$ in LS soil) (Figure 3). In comparison to the KTR treatment (126.9 $\mathrm{mg} \mathrm{P} \mathrm{pot}^{-1}$ ), AP fertilisation significantly increased P uptake only in the LS soil $\left(206.3 \mathrm{mg} \mathrm{P} \mathrm{pot}^{-1}\right)$. Irrespective of the type of soil (SL and LS), P uptake by the grass was similar in treatments fertilised with struvite (STR and STR $+N$ ) and AP. Our results support earlier findings that show that P uptake by maize was similar in the first and second year on struvite and triple superphosphate treatments in near-neutral $\mathrm{pH}$ soil [26]. Antonini et al. [33] showed that $P$ uptake by ryegrass was similar or even higher from struvite than from artificial fertiliser. Bonvin et al. [24] showed that $\mathrm{P}$ uptake from struvite and water-soluble fertiliser $\left(\mathrm{KH}_{2} \mathrm{PO}_{4}\right)$ by ryegrass cultivated on acid soil ( $\mathrm{pH}$ 5.4) was similar. Johnston and Richards [40] 
found no differences in $\mathrm{P}$ uptake from struvite and monocalcium phosphate fertiliser by ryegrass cultivated on soils with a near-neutral soil pH. Everaert et al. [30] obtained a higher phosphorus uptake by plants from ammonium phosphate than from struvite. In our study, in the second year of the experiments, plants treated with struvite took up N and P more effectively than the ammonium phosphate-treated plants.

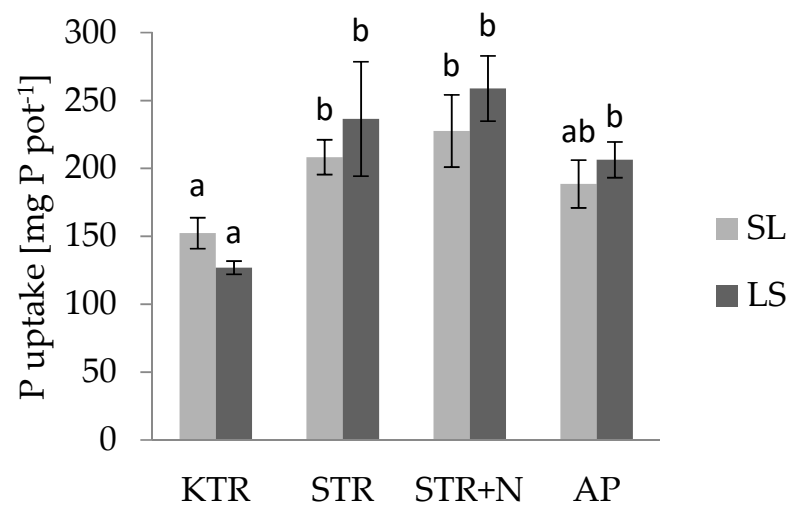

Figure 3. Uptake of $P$ by grass (sum for four harvests). The standard deviation within each treatment $(n=3)$ is indicated by the line extending from the column. Different letters $(a, b)$ indicate significant differences $(p<0.05)$.

In SL soil, no differences were found in the uptake of $\mathrm{Mg}$ by grass cultivated with the treatments STR, STR + N, and AP. The mean Mg uptake after these treatments (285.7 $\mathrm{mg} \mathrm{Mg} \mathrm{pot}^{-1}$ ) was approx. $47.5 \%$ higher than from the KTR treatment (193.9 $\mathrm{mg} \mathrm{Mg} \mathrm{pot}^{-1}$ ) (Figure 4). In LS soil, magnesium uptake by grass was significantly higher in the treatments fertilised with STR and STR $+\mathrm{N}\left(283.6 \mathrm{mg} \mathrm{Mg} \mathrm{\text {pot } ^ { - 1 }}\right.$

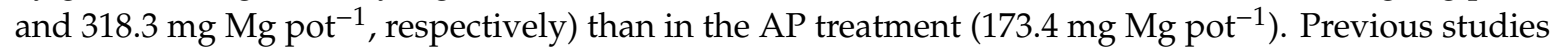
are in agreement with our finding. Uysal et al. [43] reported that tomatoes and corn took up a higher amount of Mg from struvite than from NPK fertiliser.

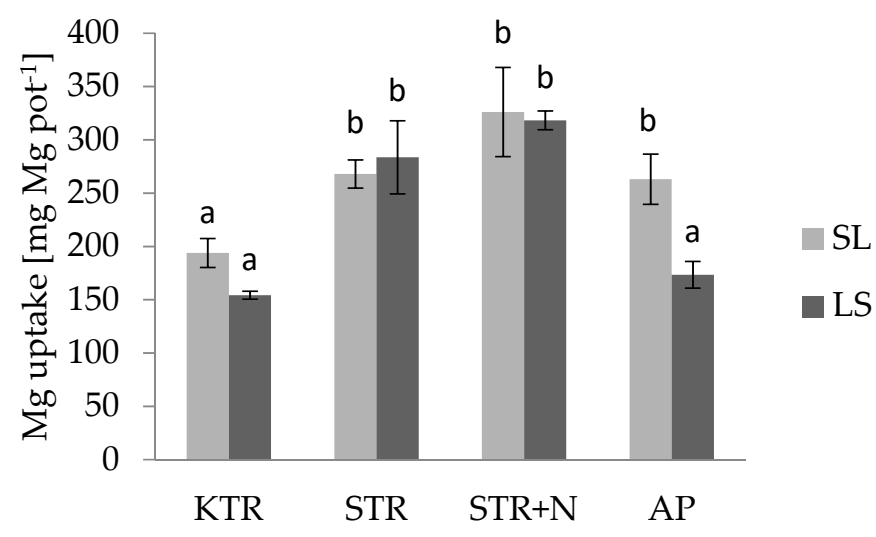

Figure 4. Uptake of $\mathrm{Mg}$ (sum for four harvests) by grass. The standard deviation within each treatment $(n=3)$ is indicated by the line extending from the column. Different letters $(a, b)$ indicate significant differences $(p<0.05)$.

\subsection{Phosphorus- and Nitrogen-Use Efficiency}

The related fertiliser efficiency (REF) characterises the effectiveness of fertiliser and allows for comparison of different fertilisers (in this case struvite and ammonium phosphate). In the second year of the experiment, struvite was more effective than the ammonium phosphate fertiliser (except for REF $_{\mathrm{N}}$ in the STR treatment, in SL soil) (Table 3). In contrast, Cabeza et al. [26] observed in acid 
and neutral soils a similar efficiency of struvite and triple superphosphate in the second year after fertiliser application.

In the grass cultivation on SL soil, the highest apparent recovery of applied N (ANR) was found from struvite with ammonium sulphate (STR + N). In LS soil, ANR from the STR and STR + N treatments was higher by $100 \%$ and $48 \%$, respectively, compared to the AP treatment. In the second year after fertiliser application, the ANR from the STR treatments were approximately 10 times higher and, from the STR $+\mathrm{N}$ treatment approximately 5 times higher than from the AP treatment. This suggests that plants very efficiently use the nitrogen contained in struvite, especially in light soils.

Table 3. Related fertiliser efficiency (REF) (\%) of STR and STR + N.

\begin{tabular}{ccccc}
\hline \multirow{2}{*}{ Fertiliser } & \multicolumn{2}{c}{ SL } & \multicolumn{2}{c}{ LS } \\
\cline { 2 - 5 } & $\mathbf{R E F}_{\mathbf{N}}$ & $\mathbf{R E F}_{\mathbf{P}}$ & $\mathbf{R E F}_{\mathbf{N}}$ & $\mathbf{R E F}_{\mathbf{P}}$ \\
\hline STR & $39.7 \mathrm{a}$ & $154.5 \mathrm{a}$ & $526.8 \mathrm{a}$ & $138.0 \mathrm{a}$ \\
$\mathrm{STR}+\mathrm{N}$ & $214.3 \mathrm{~b}$ & $207.8 \mathrm{a}$ & $681.2 \mathrm{a}$ & $166.2 \mathrm{a}$ \\
$\mathrm{AP}$ & 100.0 & 100.0 & 100.0 & 100.0 \\
\hline
\end{tabular}

$\mathrm{RFE}_{\mathrm{N}}$-nitrogen relative fertiliser efficiency; RFE - phosphorus relative fertiliser efficiency. Values followed by the same letters $(a, b)$ in the column are not statistically different $(p<0.05)$.

Nevertheless, the apparent recovery of applied P (APR) by plants was low, both in the first and second year after fertilisation. In the first year, the highest phosphorus utilization in SL soil was from the AP treatment. In the second year, the APR was higher from the struvite treatments (STR, STR $+\mathrm{N})$. Compared with the AP treatment, the efficiency of using phosphorus from the STR and STR $+\mathrm{N}$ treatments was higher by $54 \%$ and $108 \%$, respectively. A similar relationship was found in the LS soils, in which, in the second year after fertilisation, the APR after the STR treatment was higher by $38 \%$, and that after STR $+\mathrm{N}$ was higher by $66 \%$ than after the AP treatment.

\subsection{Effect of Subsequent Struvite Fertilisation on Properties of SL and LS Soil}

The content of total nitrogen, as well as the active and available forms of phosphorus and magnesium was different in both soils (Table 4). Irrespective of the applied fertilisation, SL soil showed a lower degree of acidification and a higher content of total nitrogen and active $\left(\mathrm{Mg}_{\mathrm{CaCl}}\right)$ and available $\left(\mathrm{Mg}_{\mathrm{M} 3}\right)$ forms of magnesium than LS soil. More active $\left(\mathrm{P}_{\mathrm{CaCl} 2}\right)$ and available $\left(\mathrm{P}_{\mathrm{M} 3}\right)$ forms of phosphorus were found in LS soil than in SL soil. The applied fertilisation practically did not differentiate the content of the total nitrogen, neither in SL soil nor in LS soil. It did affect the $\mathrm{pH}$ of the analysed soils. AP application reduced the $\mathrm{pH}$ of both analysed soils in comparison to the KTR treatments. This is confirmed by the opinion known from the literature that mineral fertilisation increases soil acidification [51]. In the second year after the application of struvite (STR and STR $+\mathrm{N}$ ), the $\mathrm{pH}$ of the SL soil was similar to that in the KTR treatment. The $\mathrm{pH}$ of the LS soil in the STR treatment was higher than in the KTR treatment. It could result from the presence of magnesium in struvite. Its neutralising power is 1.4 times higher than the neutralising power of $\mathrm{Ca}$ [52] and the buffering activity of phosphate ions released from struvite. Research on the effect of struvite on soil $\mathrm{pH}$ was also conducted by Talboys et al. [29]. In their study, after 2 days of struvite application, soil $\mathrm{pH}$ increased from $\mathrm{pH}$ 5.5, 6.0, and 6.5 to $\mathrm{pH}$ 6.9-7.1. Rohman [49] also reported that struvite applied in acidic soil increased the soil $\mathrm{pH}$. It should be emphasised that struvite supplementation with ammonium sulphate, which usually strongly acidifies the soil, caused no decrease in $\mathrm{pH}$, although on light soil (LS) the $\mathrm{pH}$ after the STR + N treatment was lower than after the STR treatment. Light soils are characterised by lower buffer properties in comparison to medium soils [52]. As a result, they are more prone to changes in $\mathrm{pH}$ caused by the applied fertilisation.

$P$ concentration in the $0.01 \mathrm{~mol} \mathrm{dm}^{-3} \mathrm{CaCl}_{2}$ extract $\left(\mathrm{P}_{\mathrm{CaCl}}\right)$ is similar to that in the soil solution [53]. The highest content of active forms of phosphorus $\left(\mathrm{P}_{\mathrm{CaCl}}\right)$ was observed in LS soil fertilised with struvite (STR) (Table 4). The fertilisation applied in the experiment significantly differentiated the 
content of $\mathrm{P}_{\mathrm{CaCl}}$, also in SL soil, but the observed differences in $\mathrm{P}_{\mathrm{CaCl} 2}$ content in the soil were lower than in LS soil. The lower content of $\mathrm{P}_{\mathrm{CaCl} 2}$ in the STR $+\mathrm{N}$ treatment than in the STR treatment could be due to differences in the soil $\mathrm{pH}$. Lower soil $\mathrm{pH}$ after the STR $+\mathrm{N}$ treatment than after the STR treatment could have contributed to an increase in the chemical sorption of the phosphate ions contained in the soil solution due to $\mathrm{P}$ fixation [49]. Our findings correspond with other studies results. Another finding has been reported, however, in that a lower soil $\mathrm{pH}$ results in higher solution concentrations of $\mathrm{P}$ in the soil due to faster struvite dissolution [22]. The differences in soil properties presented in this work were observed after the second growing period. The comparison of the content of active forms of phosphorus in SL soil obtained in the year of application of struvite [35] suggests that struvite increased the content of $\mathrm{P}_{\mathrm{CaCl} 2}$ in light soil both in the first and second year after its application. AP increased the content of $\mathrm{P}_{\mathrm{CaCl} 2}$ in light soil in the first year after application. Rech et al. [54] recorded a peak of phosphorus content in the soil solution (mean $1609 \mathrm{mg} \mathrm{P} \mathrm{L}^{-1}$ ) on the first day after the triple superphosphate application. Subsequently, it dropped down progressively, reaching three weeks later the level similar to the background (mean $5.5 \mathrm{mg} \mathrm{P} \mathrm{L}^{-1}$ ). On the struvite fertilised treatment, the P concentration at the beginning of the experiment was low and gradually increased over the experimental period.

Table 4. Soil $\mathrm{pH}$, content of total nitrogen $\left(\mathrm{g} \mathrm{N}_{\text {tot }} \mathrm{kg}^{-1}\right)$, and active $\left(\mathrm{mg} \mathrm{P}_{\mathrm{CaCl} 2} \mathrm{~kg}^{-1}\right)$ and available (mg $\mathrm{P}_{\mathrm{M} 3} \mathrm{~kg}^{-1}$ ) forms of nutrients in SL and LS soils.

\begin{tabular}{ccccccc}
\hline Treatment & $\mathbf{p H}$ & $\mathbf{N}_{\text {tot }}$ & $\mathbf{P}_{\mathrm{CaCl} 2}$ & $\mathbf{P}_{\mathrm{M} 3}$ & $\mathbf{M g}_{\mathrm{CaCl} 2}$ & $\mathbf{M g}_{\mathrm{M} 3}$ \\
\hline \multicolumn{7}{c}{} \\
& $6.3 \mathrm{a}$ & $2.3 \mathrm{~ns}$ & $1.44 \mathrm{a}$ & $16.54 \mathrm{a}$ & $142.51 \mathrm{a}$ & $314.71 \mathrm{a}$ \\
KTR & $6.5 \mathrm{a}$ & $2.5 \mathrm{~ns}$ & $6.37 \mathrm{c}$ & $192.78 \mathrm{c}$ & $244.13 \mathrm{~b}$ & $594.09 \mathrm{~b}$ \\
STR & $6.4 \mathrm{a}$ & $2.4 \mathrm{~ns}$ & $4.40 \mathrm{~b}$ & $214.28 \mathrm{c}$ & $341.40 \mathrm{c}$ & $621.83 \mathrm{~b}$ \\
STR + N & $5.8 \mathrm{~b}$ & $2.6 \mathrm{~ns}$ & $2.09 \mathrm{a}$ & $79.40 \mathrm{~b}$ & $144.33 \mathrm{a}$ & $344.83 \mathrm{a}$ \\
AP & & & & LS soil & & \\
\hline & & & & & \\
KTR & $5.5 \mathrm{a}$ & $0.84 \mathrm{~ns}$ & $0.63 \mathrm{a}$ & $62.63 \mathrm{a}$ & $22.61 \mathrm{a}$ & $41.25 \mathrm{a}$ \\
STR & $6.7 \mathrm{a}$ & $0.69 \mathrm{~ns}$ & $38.87 \mathrm{~d}$ & $320.07 \mathrm{~d}$ & $175.85 \mathrm{c}$ & $366.18 \mathrm{c}$ \\
STR + N & $5.7 \mathrm{a}$ & $0.67 \mathrm{~ns}$ & $25.15 \mathrm{c}$ & $234.38 \mathrm{c}$ & $111.07 \mathrm{~b}$ & $186.86 \mathrm{~b}$ \\
AP & $5.1 \mathrm{~b}$ & $0.70 \mathrm{~ns}$ & $7.19 \mathrm{~b}$ & $207.42 \mathrm{~b}$ & $24.76 \mathrm{a}$ & $51.89 \mathrm{a}$
\end{tabular}

Values followed by the same letters (a-d) in the column (separately for soils: SL and LS) are not statistically different $(p<0.05)$; ns: not significant.

The applied fertilisation also affected the content of forms of phosphorus available for plants, extracted from the soil with Mehlich 3 solution $\left(\mathrm{P}_{\mathrm{M} 3}\right.$ ) (Table 4). In both types of soil, a higher content of these forms of phosphorus was found in treatments fertilised with struvite (STR and STR + N) than ammonium phosphate (AP). Rech et al. [54] and Vogel et al. [55] reported that struvite had a higher residual value than triple superphosphate (TSP), and left greater amounts of $\mathrm{P}$ in the soil compared to TSP. Our study confirms these results. In the second year after the struvite application, the content of $\mathrm{P}_{\mathrm{M} 3}$ in the soil on the STR treatment was approx. 11\% higher than in the first year of the study [35]. The decrease in $\mathrm{P}_{\mathrm{M} 3}$ content in soil on the AP treatment observed both in SL and LS soils in the second year after fertiliser application suggests that the phosphorus was largely mobilised from the fertiliser already in the first year of the study. The released phosphorus could have been subject to uptake by the cultivated grass. Cabeza et al. [26] reported that, in the first year, P uptake by maize plants was twice as large for triple superphosphate (TSP) than the unfertilised control, while in the second year, $P$ uptake in the TSP-fertilised treatment strongly decreased, particularly in the acid soil.

The study shows that struvite is a good source of magnesium, accumulated in the soil in both the inactive and available forms (Table 4). Its fertiliser application can therefore solve the problem of magnesium deficit existing in the soils of Central and Eastern Europe. A significant increase in the content of these forms of magnesium in SL and LS soils was observed already in the first year after struvite application [35]. In the second year after the struvite application, a further increase in magnesium content in the soils was observed. The highest content of active forms of magnesium 
$\left(\mathrm{Mg}_{\mathrm{CaCl} 2}\right)$ in SL soil was found in soil fertilised with STR $+\mathrm{N}$. Struvite fertilisation also contributed to an increase in available forms of magnesium $\left(\mathrm{Mg}_{\mathrm{M} 3}\right)$ in SL soil (Table 4). No differences were observed between soils fertilised with STR and STR $+\mathrm{N}$. Mean $\mathrm{Mg}_{\mathrm{M} 3}$ content in soils collected from these treatments was almost twice higher than in the KTR treatment. The content of both forms of magnesium in SL soil fertilised with AP was similar to that in the KTR treatment. The highest content of $\mathrm{Mg}_{\mathrm{CaCl}}$ and $\mathrm{Mg}_{\mathrm{M} 3}$ in LS soil was found in the STR treatment. The soils fertilised with STR and STR + N showed a significantly $(p<0.05)$ higher magnesium content than soils collected after the AP treatment.

The results show that the release of nutrients ( $\mathrm{P}$ and $\mathrm{Mg}$ ) from struvite particularly occurs in the first and second year after its application. It should be emphasised, however, that our study assessed the nutrient availability of very small struvite crystals derived from a bio-refinery. Their linear dimension was approx. $1400 \mu \mathrm{m}$ [38]. Our results could not be applied to commercial granular struvites, because the struvite dissolution rate is lower for granular struvite [56], and depends on excess base added during the fertiliser granulation process [22]. Nonetheless, insufficient evidence is published to characterise the impact of granular struvite on crop yields and soil properties and further field-scale investigations are needed.

\section{Conclusions}

The results of our study demonstrate that struvite recovered from the liquid fraction of the bio-refineries' digestates is a valuable sustainable complex fertilizer for agricultural applications. In the second year past the fertilisation, the averaged grass yields from the four harvests after the struvite treatments (STR and STR + N) in SL and LS soils exceeded those from the commercial ammonium phosphate treatment, approximately by $8 \%$ and $16.5 \%$, respectively. The related $\mathrm{N}$ efficiency under the STR + N treatment on SL and LS soils, respectively, exceeded that than under the AP treatment, being 2- and 6-fold higher. The related P efficiency under the struvite treatments was approximately 2 -fold higher than that under the AP-treated soils. A significantly $(p<0.05)$ higher content of active and available phosphorus and magnesium was observed in the soil fertilised with struvite than in that treated with commercial ammonium phosphate. Our results confirm that struvite is more effective as a fertiliser than commercial ammonium phosphate. Furthermore, we have evidenced that struvite releases nutrients both in the first and second year after fertilisation. Struvite yield potential is maintained in the second growing period following the application. In practice, this may reduce the costs of fertilisation of grasslands through the application of accumulated doses of struvite once in two years. Recovered struvite should be recommended for application in soils with a low and very low magnesium content. To obtain better production results, it is recommended to supplement struvite fertilisation with nitrogen and potassium fertilisers.

Author Contributions: Conceptualization: G.W.P.v.P., R.L.C. and M.S.; methodology: M.S.; formal analysis: M.S., T.S. and A.W.; investigation: M.S., A.B., U.D. and E.S.; writing—original draft preparation: M.S.; writing一review and editing: T.S., A.W., A.M.-R. and P.S.; visualization: M.S. and T.S.; project administration: G.W.P.v.P., R.L.C. and A.W. All authors have read and agreed to the published version of the manuscript.

Funding: This research was funded by the National Centre for Research and Development. Contracts No: BIOENERGY/CtoCfarming/03/2016. Project "Cradle to cattle farming".

Acknowledgments: The authors are grateful to Cornelissen Consulting Services Services BV. ProfiNutrients BV. and Pieter Teeuwen for the valuable collaboration during this project and for providing the materials: struvite from bio-refinery. We also wish to thank the laboratory staff of the Department of Agricultual Chemistry of the Warsaw University of Life Sciences: H. Majcher and M. Korc for professional assistance in conducting the pot experiment.

Conflicts of Interest: The authors declare no conflict of interest. 


\section{References}

1. Zhang, T.; He, X.; Deng, Y.; Tsang, D.C.W.; Jiang, R.; Becker, G.C.; Kruse, A. Phosphorus recovered from digestate by hydrothermal processes with struvite crystallization and its potential as a fertilizer. Sci. Total Environ. 2019, 698, 134240. [CrossRef] [PubMed]

2. Desmidt, E.; Ghyselbrecht, K.; Zhang, Y.; Pinoy, P.; Van der Bruggen, B.; Verstraete, W.; Rabaey, K.; Meesschaert, B. Global Phosphorus Scarcity and Full-Scale P-Recovery Techniques: A Review. Crit. Rev. Environ. Sci. Technol. 2015, 45, 336-384. [CrossRef]

3. Heffer, P.M.; Prud'homme, M.; Muirheid, B.; Isherwood, K.F. Phosphorus Fertilization Issues and Outlook; International Fertilizer Society: York, UK, 2006; Volume 586, p. 32.

4. Zalewski, A. The Global Market of Mineral Fertilizers, Taking into Account Changes in the Prices of Direct Energy Carriers and Raw Materials; Instytut Ekonomiki Rolnictwa i Gospodarki Żywnościowej PIB: Warsaw, Poland, 2014; p. 122.

5. Chrispim, M.C.; Scholz, M.; Nolasco, M.A. Phosphorus recover from municipal wastewater treatment: Critical review of challenges and opportunities for developing countries. J. Environ. Manag. 2019, 248, 109268. [CrossRef] [PubMed]

6. Kataki, S.; West, H.; Clarke, M.; Baruah, D.C. Phosphorus recovery as struvite from farm, municipal and industrial waste: Feedstock suitability, methods and pre-treatments. Waste Manag. 2016, 49, 437-454. [CrossRef] [PubMed]

7. Iacovidou, E.; Velis, C.A.; Purnell, P.; Zwirner, O.; Brown, A.; Hahladakis, J.; Millward-Hopkins, J.; Williams, P.T. Metrics for optimising the multi-dimensional value of resources recovered from waste in a circular economy: A critical review. J. Clean Prod. 2017, 166, 910-938. [CrossRef]

8. Velenturf, A.P.M.; Purnell, P. Resource Recovery from Waste: Restoring the Balance between Resource Scarcity and Waste Overload. Sustainability 2017, 9, 1603. [CrossRef]

9. Akhiar, A.; Battimelli, A.; Torrijos, M.; Carrere, H. Comprehensive characterization of the liquid fraction of digestates from full-scale anaerobic co-digestion. Waste Manag. 2017, 59, 118-128. [CrossRef]

10. Bernas, J.; Moudrý, J., Jr.; Jelinkova, Z.U.; Kopecky, M.A. Greenhouse gasses emissions during maize growing for energy purposes. In MendelNet 2014; Mendelu: Brno, Czech Republic, 2014; pp. $219-223$. ISBN 978-80-7509-174-1.

11. Bernas, J.; Moudrý, J., Jr.; Kopecký, M.; Konvalina, P.; Štěrba, Z. Szarvasi-1 and Its Potential to Become a Substitute for Maize Which Is Grown for the Purposes of Biogas Plants in the Czech Republic. Agronomy 2019, 9, 98. [CrossRef]

12. Szymańska, M.; Nowaczewska, D.; Świerżewska, E.; Wrzosek-Jakubowska, J.; Gworek, B. An attempt to assess physicochemical properties of soil fertilized with fresh and treated digestate from biogas plant. Przem. Chem. 2016, 95, 572-576.

13. Rehl, T.; Müller, J. Life cycle assessment of biogas digestate processing technologies. Res. Conserv. Recycl. 2011, 56, 92-104. [CrossRef]

14. Szymańska, M.; Sosulski, T.; Szara, E.; Pilarski, K. Conversion and properties of anaerobic digestates from biogas production. Przem. Chem. 2015, 94, 1419-1423.

15. Tao, W.; Fattah, K.P.; Huchzermeier, M.P. Struvite recovery from anaerobically digested dairy manure: A review of application potential and hindrances. J. Environ. Manag. 2016, 169, 46-57. [CrossRef] [PubMed]

16. Li, X.; Guo, J.; Dong, R.; Ahring, B.K.; Zhang, W. Properties of plant nutrient: Comparison of two nutrient recovery techniques using liquid fraction of digestate from anaerobic digester treating pig manure. Sci. Total Environ. 2016, 544, 774-781. [CrossRef] [PubMed]

17. Xia, A.; Murphy, J.D. Microalgal cultivation in treating liquid digestate from biogas systems. Trends Biotechnol. 2016, 34, 264-275. [CrossRef]

18. Kataki, S.; West, H.; Clarke, M.; Baruah, D.C. Phosphorus recovery as struvite: Recent concerns for use of seed, alternative Mg source, nitrogen conservation and fertilizer potential. Res. Conserv. Recycl. 2016, 107, 142-156. [CrossRef]

19. Bolzonella, D.; Fatone, F.; Gottardo, M.; Frison, N. Nutrients recovery from anaerobic digestate of agro-waste: Techno-economic assessment of full scale applications. J. Environ. Manag. 2018, 216, 111-119. [CrossRef] [PubMed] 
20. Ovsyannikova, E.; Kruse, A.; Becker, G.C. Feedstock-Dependent Phosphate Recovery in a Pilot-Scale Hydrothermal Liquefaction Bio-Crude Production. Energies 2020, 13, 379. [CrossRef]

21. Li, B.; Boiarkina, I.; Huang, H.M.; Munir, T.; Wang, G.Q.; Young, B.R. Phosphorus recovery through struvite crystallization: Challenges for future design. Sci. Total Environ. 2019, 648, 1244-1256. [CrossRef]

22. Degryse, F.; Baird, R.; da Silva, R.C.; McLaughlin, M.J. Dissolution rate and agronomic effectiveness of struvite fertilizers - effect of soil pH, granulation and base excess. Plant Soil. 2017, 410, 139-152. [CrossRef]

23. Withers, P.J.A.; Sylvester-Bradley, R.; Jones, D.L.; Healey, J.R.; Talboys, P.J. Feed the crop not the soil: Rethinking phosphorus management in the food chain. Environ. Sci. Technol. 2014, 48, 6523-6530. [CrossRef]

24. Bonvin, C.; Etter, B.; Udert, K.M.; Frossard, E.; Nanzer, S.; Tamburini, F.; Oberson, A. Plant uptake of phosphorus and nitrogen recycled from synthetic source-separated urine. Ambio 2015, 44 (Suppl. 2), 217-227. [CrossRef] [PubMed]

25. Kahiluoto, H.; Kuisma, M.; Ketoja, E.; Salo, T.; Heikkinen, J. Phosphorus in manure and sewage sludge more recyclable than in soluble inorganic fertilizer. Environ. Sci. Technol. 2015, 49, 2115-2122. [CrossRef] [PubMed]

26. Cabeza, R.; Steingrobe, B.; Römer, W.; Claassen, N. Effectiveness of recycled P products as P fertilizers, as evaluated in pot experiments. Nutr. Cycl. Agroecosyst. 2011, 91, 173-184. [CrossRef]

27. Ehmann, A.; Bach, I.M.; Laopeamthong, S.; Bilbao, J.; Lewandowski, I. Can phosphate salts recovered from manure replace conventional phosphate fertilizer? Agric 2017, 7, 1. [CrossRef]

28. Uysal, A.; Y1lmazel, Y.D.; Demirer, G.N. The determination of fertilizer quality of the formed struvite from effluent of a sewage sludge anaerobic digester. J. Hazard. Mater. 2010, 181, 248-254. [CrossRef]

29. Talboys, P.J.; Heppell, J.; Roose, T.; Healey, J.R.; Jones, D.J.; Withers, P.J.A. Struvite: A slow-release fertilizer for sustainable phosphorus management? Plant Soil. 2016, 401, 109-123. [CrossRef]

30. Everaert, M.; Da, R.S.; Degryse, F.; Mclaughlin, M.J.; Smolders, E. Limited dissolved phosphorus runoff losses from layered double hydroxide and struvite fertilizers in a rainfall simulation study. J. Environ. Qual. 2018, 47, 371-377. [CrossRef]

31. Plaza, C.; Sanz, R.; Clemente, C.; Fernandez, J.M.; Gonzalez, R.; Polo, A.; Colmenarejo, M.F. Greenhouse evaluation of struvite and sludges from municipal wastewater treatment works as phosphorus sources for plants. J. Agric. Food Chem. 2007, 55, 8206-8212. [CrossRef]

32. Liu, Y.H.; Rahman, M.M.; Kwag, J.H.; Kim, J.H.; Ra, C.S. Eco-friendly production of maize using struvite recovered from swine wastewater as a sustainable fertilizer source. Asian Aust. J. Anim. Sci. 2011, 24, 1699-1705. [CrossRef]

33. Antonini, S.; Arias, M.A.; Eichert, T.; Clemens, J. Greenhouse evaluation and environmental impact assessment of different urine-derived struvite fertilizers as phosphorus sources for plants. Chemosphere 2012, 89, 1202-1210. [CrossRef]

34. Gonzalez-Ponce, R.; Lopez-de-Sa, E.G.; Plaza, C. Lettuce response to phosphorus fertilization with struvite recovered from municipal wastewater. HortScience 2009, 44, 426-430. [CrossRef]

35. Szymańska, M.; Szara, E.; Wąs, A.; Sosulski, T.; van Pruissen, G.W.; Cornelissen, R.L. Struvite-An Innovative Fertilizer from Anaerobic Digestate Produced in a Bio-Refinery. Energies 2019, 12, 296. [CrossRef]

36. Ackerman, J.N.; Zvomuya, F.; Cicek, N.; Flaten, D. Evaluation of manure-derived struvite as a phosphorus source for canola. Can. J. Plant Sci. 2013, 93, 419-424. [CrossRef]

37. Hertzberger, A.J.; Cusick, R.D.; Margenot, A.J. A review and meta-analysis of the agricultural potential of struvite as a phosphorus fertilizer. Soil Sci. Soc. Am. J. 2020, 84, 653-671. [CrossRef]

38. Szymańska, M.; Szara, E.; Sosulski, T.; Wąs, A.; Van Pruissen, G.W.P.; Cornelissen, R.L.; Borowik, M.; Konkol, M. A Bio-Refinery Concept for N and P Recovery-A Chance for Biogas Plant Development. Energies 2019, 12, 155. [CrossRef]

39. Reza, A.; Shim, S.; Kim, S.; Ahmed, N.; Won, S.; Ra, C. Nutrient Leaching Loss of Pre-Treated Struvite and Its Application in Sudan Grass Cultivation as an Eco-Friendly and Sustainable Fertilizer Source. Sustainability 2019, 11, 4204. [CrossRef]

40. Johnston, A.E.; Richards, I.R. Effectiveness of different precipitated phosphates as phosphorus sources for plants. Soil Use Manag. 2003, 19, 45-49. [CrossRef]

41. Yetilmezsoy, K.; Turkdogan, F.I.; Gunay, A.; Yilmaz, T.; Kaleli, M. Medicinal plants grown in soil amended with struvite recovered from anaerobically pretreated poultry manure wastewater. J. Anim. Plant Sci. 2013, $23,261-270$. 
42. Uysal, A.; Kuru, B. Magnesium ammonium phosphate production from wastewater through Box-Behnken design and its effect on nutrient element uptake in plants. Clean Soil Air Water 2013, 41, 447-454. [CrossRef]

43. Uysal, A.; Demir, S.; Sayilgan, E.; Eraslan, F.; Kucukyumuk, Z. Optimization of struvite fertilizer formation from baker's yeast wastewater: Growth and nutrition of maize and tomato plants. Environ. Sci. Pollut. Res. 2014, 21, 3264-3274. [CrossRef]

44. Prabhu, M.; Mutnuri, S. Cow urine as a potential source for struvite production. Int. J. Recycl. Org. Waste Agric. 2014, 3, 1-12. [CrossRef]

45. Gell, K.; Ruijter, F.J.; Kuntke, P.; Graaff, M.; Smit, A.L. Safety and effectiveness of struvite from black water and urine as a phosphorus fertilizer. J. Agric. Sci. 2011, 3, 67-80. [CrossRef]

46. Kern, B.; Heinzmann, B.; Markus, B.; Kaufmann, A.C.; Soethe, N.; Engels, C. Recycling and assessment of struvite phosphorus from sewage sludge. Agric. Eng. Int. 2018, 10, 1-13.

47. Ryu, H.D.; Lim, C.S.; Kang, M.K.; Lee, S. Evaluation of struvite obtained from semiconductor wastewater as a fertilizer in cultivating Chinese cabbage. J. Hazard. Mater. 2012, 221, 248-255. [CrossRef] [PubMed]

48. Diwani, G.E.; Rafie, S.E.; Ibiari, N.N.; El-Aila, H.I. Recovery of ammonia nitrogen from industrial wastewater treatment as struvite slow releasing fertilizer. Desalination 2007, 214, 200-214. [CrossRef]

49. Rahman, M.d.D.; Liu, Y.; Kwag, J.-H.; Ra, C. Recovery of struvite from animal wastewater and its nutrient leaching loss in soil. J. Hazard. Mater. 2011, 186, 2026-2030. [CrossRef]

50. Latifian, M.; Liu, J.; Mattiasson, B. Struvite-based fertilizer and its physical and chemical properties. Environ. Technol. 2012, 33, 2691-2697. [CrossRef]

51. Kalkhoran, S.S.; Pannell, D.J.; Thamo, T.; White, B.; Polyakov, M. Soil acidity, lime application, nitrogen fertility, and greenhouse gas emissions: Optimizing their joint economic management. Agric. Syst. 2019, 176, 102684. [CrossRef]

52. Mercik, S. Agricultural Chemistry-Theoretical and Practical Basics; SGGW: Warsaw, Poland, 2002; p. 287.

53. Johnston, A.E.; Poulton, P.R. Phosphorus in Agriculture: A Review of Results from 175 Years of Research at Rothamsted, UK. J. Environ. Q. 2019. [CrossRef]

54. Rech, I.; Withers, P.J.A.; Jones, D.L.; Pavinato, P.S. Solubility, Diffusion and Crop Uptake of Phosphorus in Three Different Struvites. Sustainability 2019, 11, 134. [CrossRef]

55. Vogel, T.; Kruse, J.; Siebers, N.; Nelles, M.; Eichler-Lobermann, B. Recycled products from municipal wastewater: Composition and effects on phosphorus mobility in a sandy soil. J. Environ. Q. 2017, 46, 443-451. [CrossRef] [PubMed]

56. Szymańska, M.; Szara, E.; Wass, A.; Korc, M.; Borowik, M.; Zdunek, A.; Rusek, P.; Schab, S. Agronomic value of powder and granulated struvite. Przem. Chem. 2018, 97, 277-281.

Publisher's Note: MDPI stays neutral with regard to jurisdictional claims in published maps and institutional affiliations.

(C) 2020 by the authors. Licensee MDPI, Basel, Switzerland. This article is an open access article distributed under the terms and conditions of the Creative Commons Attribution (CC BY) license (http://creativecommons.org/licenses/by/4.0/). 